\section{Solid Phase Peptide Synthesis by Four Component Condensation: Peptide Formation on an Isocyano Polymer Support}

\author{
Reza Arshady* and Ivar Ugi \\ Organisch-chemisches Institut \\ der Technischen Universität München, \\ Lichtenbergstraße 4, D-8046 Garching, \\ W.-Germany
}

Z. Naturforsch. 36b, 1202-1203 (1981); received May 4, 1981

Solid Phase Peptide Synthesis, Four Component Condensation, Isocyano Polymer Support, Anchoring Technique

Coupling of various protected amino acids or small peptides on an isocyano polymer and in the presence of 1-methyl-3-formylindole demonstrates the feasibility of peptide formation by four component condensation on a polymer support, and the final peptide is detached from the resin by $50 \%$ trifluoroacetic acid in acetonitrile at room temperature.

The feasibility of peptide synthesis by four component condensation (4CC) [1] has been demonstrated [2]. In particular the advantages of peptide synthesis by $4 \mathrm{CC}$, namely coupling without carboxyl activation, the possibility of reaction in highly polar media, and the effectively unimolecular nature of the coupling step in such coupling of peptide frag. ments are being recognized [3]. The unique feature of $4 \mathrm{CC}$, i.e., the participation of four components in the reaction, provides a potentially versatile apparatus for combination with the so-called solid phase techniques [4]. In principle a number of strategies of solid phase peptide synthesis by four component condensation (SPPS-4CC) can be envisaged. Here we report some of our preliminary results on a novel strategy which is ideally suited for coupling of peptide segments on an isocyano polymer support. In addition the principle described here can be employed as an anchoring technique to initiate solid phase peptide synthesis by the stepwise (Merrifield-type) procedure [4].

According to this strategy, as outlined in SchemeI, a C-protected amino acid or peptide $\left(\mathrm{H}_{2} \mathrm{~N}-\mathrm{P}^{\mathrm{N}}\right.$, amine-component) and an N-protected amino acid or peptide ( $\mathrm{P}^{\mathrm{C}}-\mathrm{COOH}$, acid component) are coupled in the presence of an aldehyde and a polymer-bound isonitrile to produce the peptide product attached to the polymer through an auxiliary substituent on the $\mathrm{N}$-terminal of the amine component. Removal of the peptide from the polymer involves the

\footnotetext{
* Reprint request to Dr. R. Arshady.
} 0340-5087/81/0900-1202/\$01.00/0 cleavage of this auxiliary substituent, leaving the co-product attached to the polymer. Non-destructive cleavage of the auxiliary substituent is, however, of prominent importance in the successful application of the method, and depends on the structure of the aldehyde. For the present study an aldehyde with an acidolytically cleavable $4 \mathrm{CC}$ product, namely 1-methyl-3-formylindole [5], was used. (Work on the use of other cleavable aldehydes $[2,3,6]$ is in progress.) For the polymer support, and with the use of polar solvents such as alcohols in mind, we examined a number of acrylamide containing resins carrying about $1-3 \mathrm{mmol} / \mathrm{g}$ isocyano groups and having various chemical structures, cross-linking, and topography. H-Leu-OEt and Boc-Gly-Ala-OH were also chosen as model amine and acid components according to Scheme I.

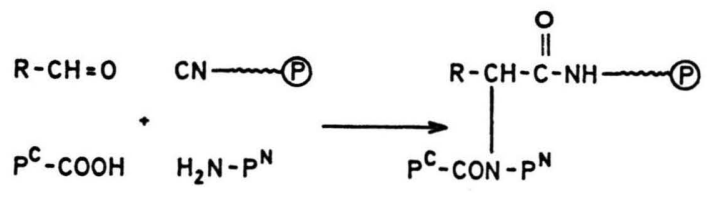

$\stackrel{\mathrm{HX}}{\longrightarrow} \mathrm{P}^{\mathrm{C}}-\mathrm{CONH}-\mathrm{P}^{\mathrm{N}}+\mathrm{R}-\mathrm{CHX}-\mathrm{CONH}-\mathrm{P}$

Scheme I. Peptide formation on an isocyano polymer support by four component condensation.

In a typical experiment the polymer $(50-100 \mathrm{mg})$, the amine, the aldehyde $(4 \mathrm{mmol} / \mathrm{g}$ polymer), and the acid ( $3 \mathrm{mmol} / \mathrm{g}$ polymer) were mixed in methanol (4-6 ml/g polymer) and allowed to stand at room temperature for $72 \mathrm{~h}$. The polymer was then filtered, washed extensively [7] with methanol, water, dimethylformamide, dioxane and ether, and dried under vacuum in the presence of $\mathrm{P}_{2} \mathrm{O}_{5}$ at room temperature. Progress of the reaction was qualitatively monitored by comparing in the i.r. the disappearance of the isocyano $\left(2170 \mathrm{~cm}^{-1}\right)$ and appearance of the ester carbonyl (shoulder at $1700-1750 \mathrm{~cm}^{-1}$ ) absorption with that of the amide carbonyl $1650 \mathrm{~cm}^{-1}$. Among several polymer types examined, 1 and 2 were found equally satisfactory and 2 was adopted for the present study. Polymer (1) was prepared by suspension copolymerization of the formamide precursor of the functional monomer (ca. $34 \mathrm{M} \%$ ) with the cross-linker (ca. $8 \mathrm{M} \%$ ) and dimethylacrylamide in the presence of waterdimethylformamide $(2: 1)$ as a solvent $(3 \mathrm{ml} / \mathrm{g}$ monomer). Polymer (2) was derived from a previously described [8] copolymer of styrene and 2,4,5trichlorophenylacrylate. The final isocyano functions were, in both cases, generated by dehydration of the formamide polymer with excess $p$-toluenesulfonylchloride in pyridine $(2: 3 \mathrm{w} / \mathrm{v})$ at room tem. perature.

In order to ascertain the formation of the peptide derivative on the polymer it was treated 


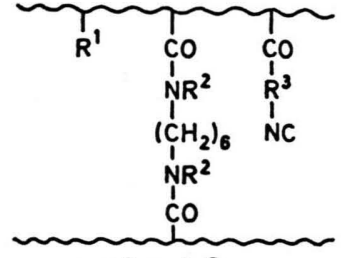

1 and 2

1: $R^{1}=\operatorname{CONMe}_{2} \cdot R^{2}=H, R^{3}=0-\left(\mathrm{CH}_{2}\right)_{3}$

2: $R^{1}=\square \cdot R^{2}=M e \cdot R^{3}=\mathrm{NH}-\left(\mathrm{CH}_{2}\right)_{6}$

with trifluoroacetic acid (TFA) in acetonitrile $(1: 1)$, and tlc (chloroform : methanol: acetic acid, 75:15:10; and propanol: acetic acid: water, $6: 2: 2$ ) of the supernatant solution showed the $\mathrm{N}$-deprotected tripeptide to be indistinguishable from the material produced by DCC condensation of the corresponding components. Qualitative i.r. spectroscopy of the polymer indicated complete cleavage of the peptide from the resin after $5 \mathrm{~h}$, as was expected from solution experiments [5]. For a quantiative estimate of the amount of polymer-bound peptide, the polymer was subjected to hydrolysis and amino acid analysis and showed (within experimental errors) about $0.5 \mathrm{mmol} / \mathrm{g}$ of the expected tripeptide per gram polymer.

These results encouraged further studies on more hindered and larger components. Thus $\mathrm{H}-\mathrm{Val}-\mathrm{OMe}$ and Fmoc-Leu-OH were condensed on the polymer in the presence of $2 \mathrm{mmol} / \mathrm{g}$ (i.e., a lower concentration) of the soluble components, and peptide formation on the polymer was examined by i.r., amino acid analysis of the polymer, and tlc of the TFA cleaved product. The amount of the dipeptide on the polymer was found to be $0.24 \mathrm{mmol} / \mathrm{g}$. However, coupling of H-Ala-val-Leu-OEt with either of Z-Gly-Phe-OH, Z-Gly-Ile-OH, or Boc-Leu-AlaGly-OH was less satisfactory, and amino acid analysis showed about $0.05-0.07 \mathrm{mmol}$ peptide per gram of the polymer, which is perhaps acceptable as the lower bound of practical peptide synthesis for these sizes.

Our attempts are presently continued to seek improved polymer supports and reaction conditions particularly for more efficient condensation of larger fragments, as well as minimized racemization. (The latter is expected to be generally low for $4 \mathrm{CC}$ in methanol, cf. ref. [3], but has bot been examined presently.)

We are indebted to Fonds der Chemischen Industrie for supporting this work.
[1] Isonitrile Chemistry, Ed. I. Ugi, Academic Press, New York 1971, Chapters 8-9.

[2] I. Ugi, in "The Peptides", Vol. 2 (Eds. J. Meienhofer and E. Gross), 1979, Academic Press, New York, pp. 365-681. I. Ugi, D. Marquarding and R. Urban, in "Chemistry and Biochemistry of Amino Acids, Peptides and Proteins", Vol. 6, ed. : B. Weinstein, Marcel Dekker, New York, 1981, p. 245.

[3] M. Waki and J. Meienhofer, J. Am. Chem Soc. 99, 6075 (1977). M. Waki, Y. Minematsu, J. Meienhofer, and N. Izumia, Chemistry Lett. 1979, 823.

[4] Cf. G. Barany and R. B. Merrifield, in "The Peptides" Eds. Gross and Meienhofer, Academic Press, New York 1980. R. Arshady, E. Atherton, L. J. Clive, and R. C. Sheppard, J. Chem. Soc.
Perkin I, 6075 (1981). Chr. Birr, "Aspects of Merrifield Peptide Synthesis", Springer-Verlag, Berlin-Heidelberg 1978.

[5] Unpublished results by $H$. von Zychlinski, to whom we are indebted for preparation of the aldehyde, as well as discussions.

[6] C. F. Hoyng and A. D. Patel, Tetrahedron Lett. $1980,4795$.

[7] In some cases we observed considerable binding of the amine component to the resin, probably as a result of the stabilizations of an intermediate, or by-product within the matrix of some of the strongly binding polymers.

[8] R. Arshady, Makromol. Chem. Rapid. Commun., 1981, in press. Preparative details of the various polymers used, and their structural effects on the efficiency of $4 \mathrm{CC}$, will be published elsewhere. 